\title{
THE LIBERATION OF NEW BRUNSWICK: AN ANTHONY WAYNE LETTER
}

\author{
BY RICHARD P. MCCORMICK
}

Dr. McCormick, professor of history at Rutgers and the university historian, has been named dean of Rutgers College, his alma mater.

7 HERE were many "turning points" in the War for Independence, but for New Jersey-and most especially for

1 New Brunswick-none was more consequential than the complete withdrawal of the British forces under General Sir William Howe at the end of June, I777. Reflecting on the event in a letter to Dr. Benjamin Rush of Philadelphia, General Anthony Wayne saw it as an unmistakable sign of "the rising Glory of America."

The incidents described by Wayne represented the culmination of a long campaign that had begun in November, I776, with Cornwallis' invasion of the state and Washington's retreat to the west bank of the Delaware River. ${ }^{2}$ The tide was turned with the American victories at Trenton and Princeton, after which Washington and his small army went into winter quarters at Morristown early in January, I777. The British, compelled to abandon their plan of maintaining garrisons in several principal towns, concentrated their forces in New Brunswick, with a secondary post at Perth Amboy. Some 5,000 troops occupied the city and its immediate environs, occasioning severe hardships for the civilian population of around I,OOO and forcing the students and faculty of Queens College to take refuge at North Branch in Somerset County. ${ }^{3}$

1. Anthony Wayne, Mount Prospect, to Dr. Benjamin Rush, Philadelphia, June 30 , 1777. This letter, which formed part of the collection of the late J. William Middendorf, Jr., of Ruxton, Maryland, was acquired through the Library's Lemuel W. Famulener Fund. It is wholly in Wayne's hand and is two-and-one-half pages in length.

${ }^{2}$ Excellent accounts of the latter phase of the New Jersey campaign may be found in Leonard Lundin, Cockpit of the Revolution: The War for Independence in New Jersey (Princeton, 1940), 306-26 and Douglas Southall Freeman, George Washington: A Biography ( 7 vols., New York, I 948-57), IV, 403-36.

${ }^{3} \mathrm{~A}$ full account of the British occupation of New Brunswick has yet to be written, but some sense of the harsh conditions that prevailed can be gleaned from Lundin, Cockpit, 217, 221-26. On the fate of Queens College, see Richard P. McCormick, Rutgers: A Bicentennial History (New Brunswick, I 966 ), I6-I 8. 
Late in May, Washington brought his army down to the Watchungs, behind Bound Brook. The area of the encampment was referred to as Middlebrook. At this location he was in a position to keep a close watch on any movements by the New Brunswick-based forces under the command of General Howe. Hoping to draw the American commander into a general action, Howe on the night of June I 3 suddenly moved the main body of his army to strong positions extending from Middlebush to Millstone. Washington prudently declined to be drawn into battle against a numerically superior force, and on June 19 the British returned to New Brunswick.

Three days later, on the morning of June 22, Washington received word that Howe's army was evacuating New Brunswick, apparently headed for Perth Amboy. Hurriedly, he ordered units under General Nathanael Greene to attempt to harass the enemy's withdrawal. ${ }^{4}$ The first to arrive at the scene were Colonel Daniel Morgan's corps of light infantry and General Wayne's Pennsylvanians. They encountered the rear guard of the British army entrenched in redoubts on the north bank of the Raritan, across from New Brunswick. The men under Morgan and Wayne gallantly charged the redoubts and the British, offering little resistance, withdrew along the road to Perth Amboy, with Morgan's riflemen pursuing them as far as Piscatawaytown." After this clash, which earned both Wayne and Morgan special commendations from General Washington, Wayne entered New Brunswick to receive the plaudits of the local patriots. ${ }^{6}$

The campaign was not yet over. On June 24 Washington advanced from Middlebrook to Quibbletown (now New Market) and placed a large force under General William Alexander, better known as Lord Stirling, at Metuchen. Thereupon Howe on June 26 launched an attack from Perth Amboy, but Stirling withdrew to Westfield and Washington dropped back to Middlebrook. Frustrated again in his efforts to bring the American army to battle, Howe returned to Perth Amboy on June 28. Two days later, abandoning any thoughts of further actions in New Jersey, he trans-

${ }^{4}$ John C. Fitzpatrick, ed., The Writings of George Washington ( 39 vols., Washington, D.C. 1931-44), VIII, 282, $29 \mathrm{r}$.

${ }^{5}$ New Jersey Archives, Second Series (5 vols., Trenton, i go I-1 7 ) I, 400-0I.

${ }^{6}$ Fitzpatrick, ed., Writings, VIII, $282-83$. 
ported his army to Staten Island. Thus the campaign that had begun so disastrously for the Americans when Cornwallis scaled the Palisades in November, I776, had now terminated with New Jersey entirely free of British troops.

An important participant in these events, "Mad Anthony" Wayne is rightly known for his impetuous bravery, as well as his brash vanity. ${ }^{7}$ Born into a prosperous family in Chester County, Pennsylvania, in I 745 , he received a good education, took an early and prominent role in the Whig cause, and was appointed a colonel in the Continental Army in January, I 776. After participating in the Canadian expedition and commanding the garrison at Fort Ticonderoga, he was promoted to the rank of brigadier-general. In May, I 777, he joined the main body of the army at Morristown, assuming command of a brigade of four Pennsylvania regiments. When the army moved to Middlebrook, Wayne took up a forward position at what was soon called "Wayne's Gap," or Mount Prospect, east of Chimney Rock in the first range of the Watchungs.

His correspondent, Dr. Benjamin Rush, had already acquired fame as a physician and politician and was to become notorious for his eccentric enthusiasms and his contentious manner. ${ }^{9} \mathrm{~A}$ native of Philadelphia, he had graduated from Princeton in 1760 at the age of fifteen. After a medical apprenticeship in Philadelphia, he studied at Edinburgh, obtaining his medical degree in 1768 . Returning to Philadelphia, he soon built a flourishing practice and involved himself in the intellectual and political life of that lively city. Early in

i The standard biography of Wayne, now sadly outdated, is Charles J. Stillé, Major General Anthony Wayne and the Pennsylvania Line in the Continental Army (Philadelphia, 1893 ).

${ }^{8}$ At Morristown Wayne's brigade included the 1 st, 2 nd, 7 th, and roth Pennsylvania regiments, and Colonel Thomas Hartley's "additional" regiment. This brigade, together with a second Pennsylvania brigade under Brigadier General John Philip De Haas formed a division under General Benjamin Lincoln. Fitzpatrick, ed., Writings, VIII, гоo. On May 26, soon after his arrival at Middlebrook, Wayne skirmished with a British party under General James Grant that had advanced from New Brunswick to within a mile of Bound Brook. Ibid., VIII, 133-34; New Jersey Archives, Second Series, I, $387,389,392$; Stillé, Wayne, 65. For identification of "Wayne's Gap," see Fitzpatrick, ed., Writings, VIII, 263,285 .

${ }^{9}$ A good recent biography is David Freeman Hawke, Benjamin Rush: Revolutionary Gadfly (Indianapolis and New York, 197 I). Also important are George W. Corner, ed,, The Autobiography of Benjamin Rush (American Philosophical Society Memoirs, number 25, Princeton, 1948) and L. H. Butterfield, ed., Letters of Benjainin Rush ( 2 volumes, American Philosophical Society Memoirs, number 3o, Princeton, I95I). 


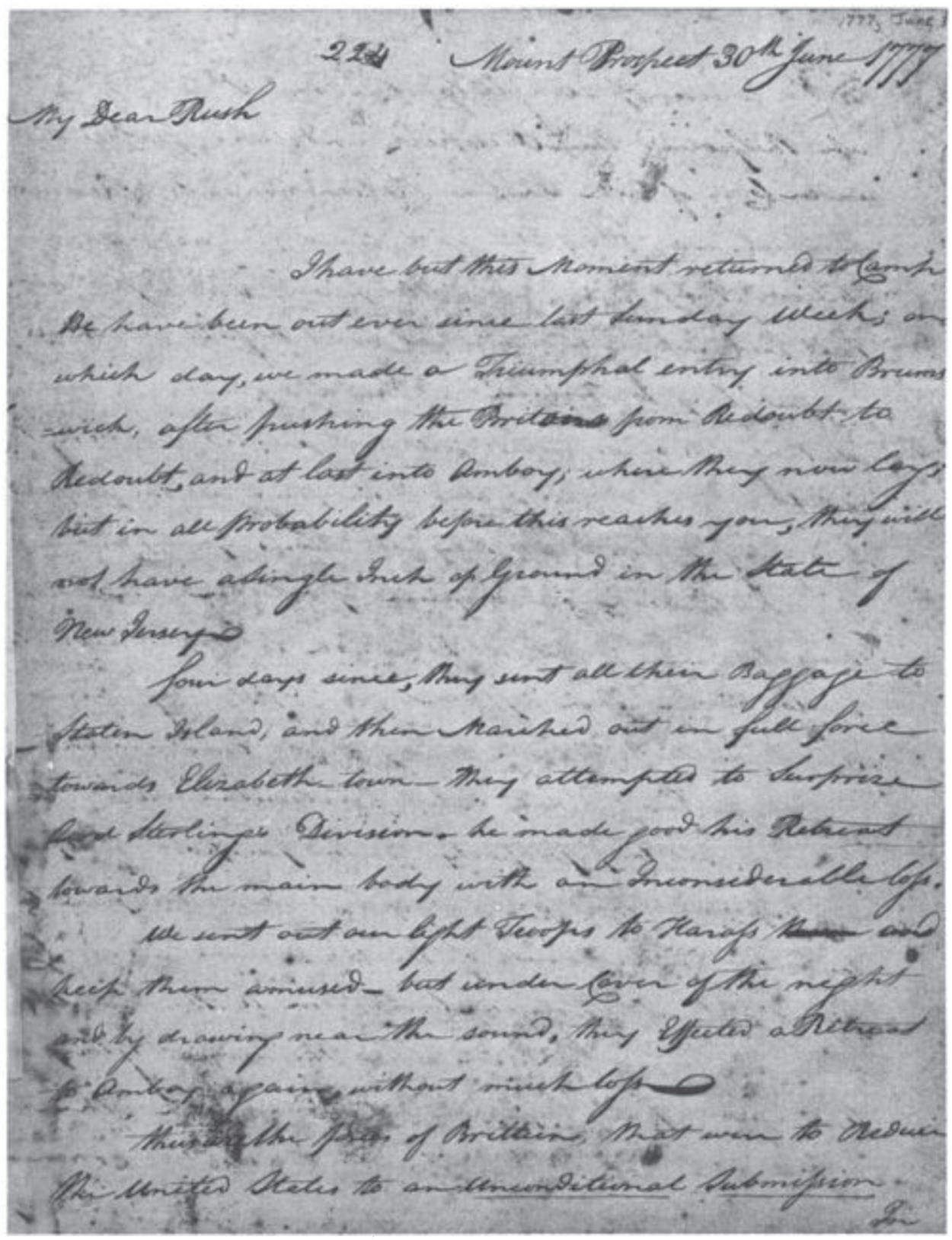


14

THE JOURNAL OF THE

in

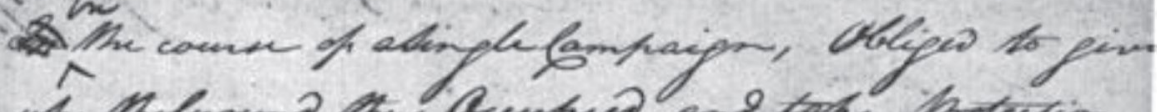

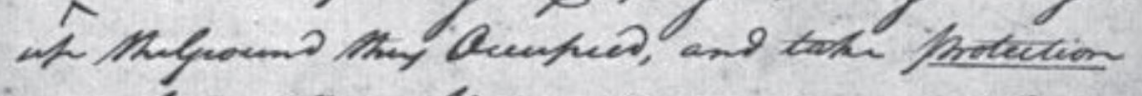

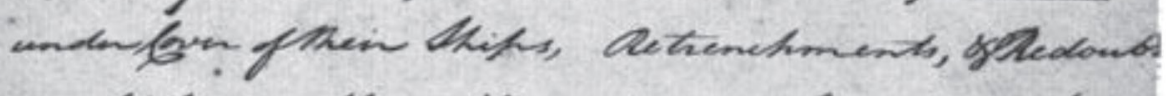
- which way they will next mare, Remains a dewey,

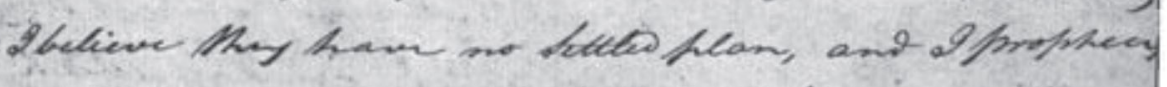
that Thlarkaipn will ens ar it began, with ow

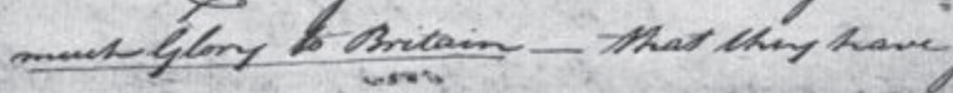

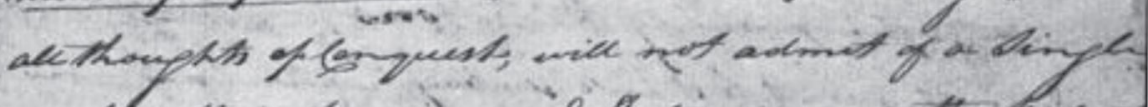

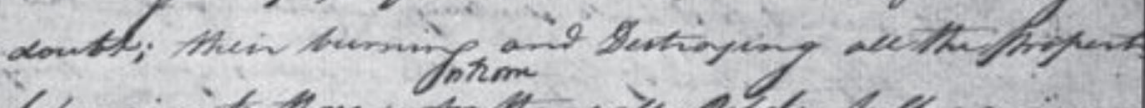

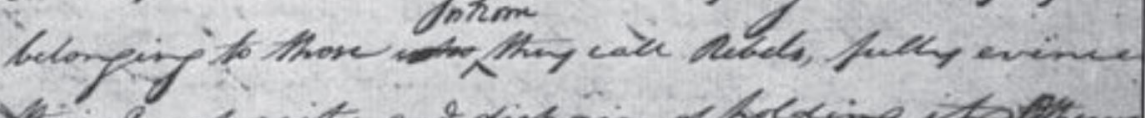

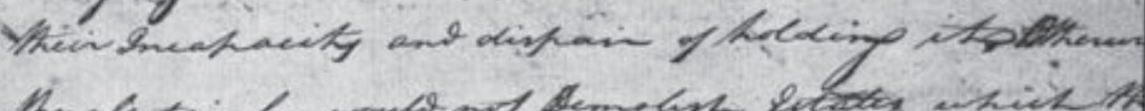

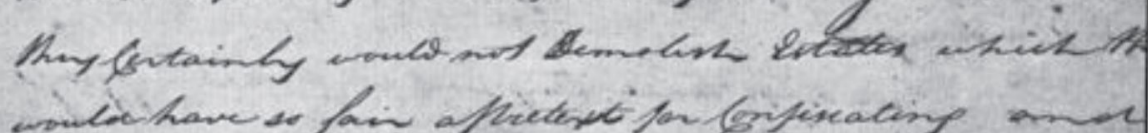

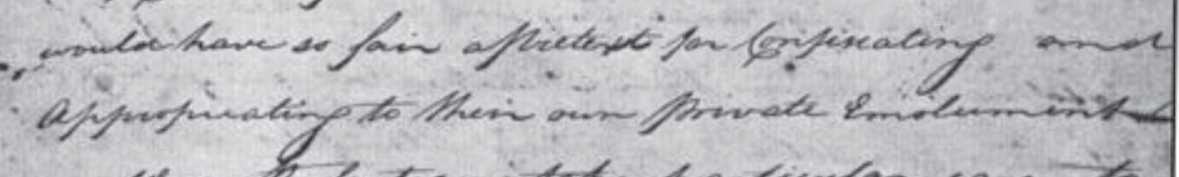
wean the bestiary tate favieular cave to

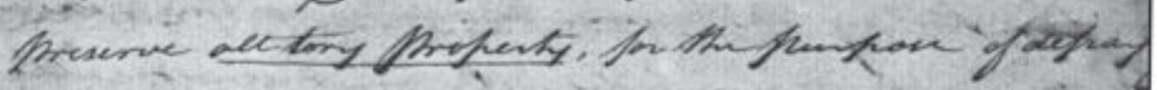

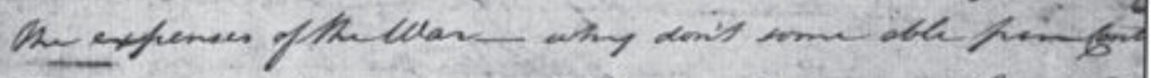

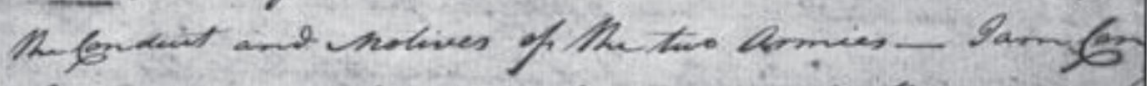

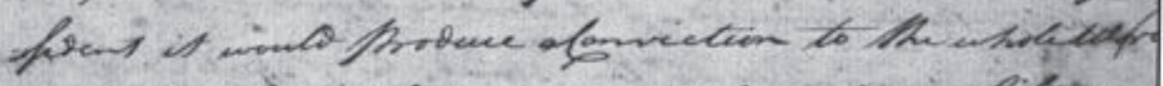

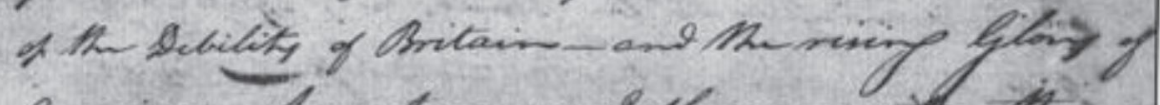

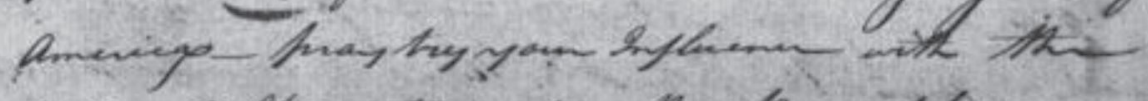

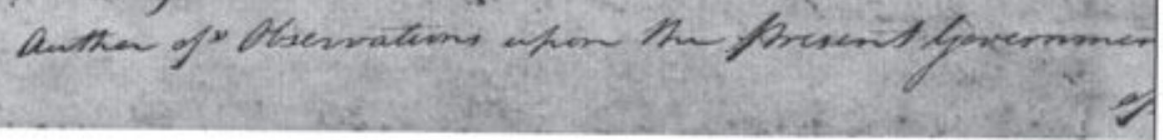


I 776 he married Julia Stockton, eldest daughter of Richard Stockton of Princeton. Soon after, as a member of the Continental Congress, he became - with his father-in-law-a signer of the Declaration of Independence.

Because of his extreme opposition to the Pennsylvania constitution, which he criticized as too unbalanced on the side of democracy, he lost his seat in the Congress and in April, I 777, he was appointed surgeon general of the army for the middle department. His involvement in the Conway Cabal brought him into conflict with Washington and ended his military career early in I778. The remainder of his life was largely devoted to propagating his distinctive medical theory and agitating for numerous humanitarian causes. During his service in Congress, he corresponded frequently with Wayne, whom he regarded as a protegé, chiefly with a view to enlisting Wayne's support for his fervent attack on the Pennsylvania constitution. ${ }^{10}$

\section{My Dear Rush}

Mount Prospect 3oth June I 777

I have but this moment returned to Camp. We have been out ever since last Sunday week; on which day, we made a Triumphal entry into $[\mathrm{New}\rceil$ Brunswick, after pushing the Britons from Redoubt to Redoubt, and at last into Amboy, where they now lay $;^{11}$ but in all probability before this reaches you, they will not have a single Inch of Ground in the State of New Jersey.

Four days since, they sent all their Baggage to Staten Island, and then marched out in full force towards Elizabeth-town. They attempted to Surprise Lord Stirling's Division. He made good his Retreat towards the main body with an Inconsiderable loss.

We sent out our light Troops to Harass and keep

${ }^{10}$ Butterfield, ed., Letters, I I4-15, i I 5n, I I6-I 7, I 36-37, I48, I49-50, $150-5$ I.

${ }^{11}$ Wayne was characteristically overexuberant in implying that the British were pushed all the way to Perth Amboy. Washington had hoped to inflict heavy losses on Howe, but his plan was not properly executed. Fitzpatrick, ed., Writings, VIII, 284 , $289,291,293,295-96,299-300$. 
them amused, but under Cover of the night and by drawing near the sound, ${ }^{12}$ they Effected a Retreat to Amboy again, without much loss.

Thus are the forces of Brittain, that were to Reduce the United States to an Unconditional Submission in the course of a single Campaign, Obliged to give up the Ground they Occupied, and take protection under Cover of their Ships, Retrenchments, \& Redoubts. Which way they will next move, Remains a Secret. I believe they have no Settled plan, and I prophecy that the Campaign will end as it began, without much Glory to Britain. ${ }^{13}$ That they have given up all thoughts of Conquest, will not admit of a Single doubt; their burning and Destroying all the property belonging to those whom they call Rebels, fully evinces their Incapacity and dispair of holding it. ${ }^{14}$ Otherwise they Certainly would not Demolish Estates which they would have so fair a pretext for Confiscating and Appropriating to their own private Emolument.

We on the Contrary take particular care to preserve all tory property, for the purpose of defraying the expenses of the war. ${ }^{15}$ Why don't some able pen Contrast the Conduct and motives of the two Armies? I am Confident it would produce a Conviction to the whole world of the Debility of Britain - and the rising Glory of America. Pray try your Influence with

12 The "sound" referred to would be the Arthur Kill, flowing between Staten Island and New Jersey. For Washington's accounts of this action, see ibid., VIII, 307-08, 308-09.

${ }^{13}$ Washington remained in doubt about Howe's plans until late in July, when it became apparent that Philadelphia was to be his next target. Freeman, Washington, IV, 435-47.

14 Washington reported that in their withdrawal from New Brunswick to Perth Amboy, the British "left nothing which they could carry off, Robbing, Plundering, and burning houses as they went." Fitzpatrick, ed., Writings, VIII, 315. See also Lundin, Cockpit, $32 \mathrm{I}$.

15 On the arrangements in New Jersey for confiscating and selling the property of convicted loyalists, see Richard P. McCormick, Experiment in Independence: New Jersey in the Critical Period, ${ }_{17} 8_{1-1789}$ (New Brunswick, 1950), $31-35$. 
the Author of "Observations upon the Present Government of Pennsylvania" to undertake the task. ${ }^{16}$

I am truly happy in having it in my power to serve the Brotherinlaw of my friend. ${ }^{17}$ You will please to present him with the Enclosed, and tell him that he is anxiously looked for on this Ground-where Doctr Rushes presence would afford pleasure to many-but to none more than to

Anty. Wayne

Just as I was about Sealing this an express from B Genl Scott ${ }^{18}$ Confirms our being in full possession of Amboy. The Caitifs are now exactly on the same Ground they Occupied this time twelve months-so that they may now agreeably to the law Phrase begin Denovo.

\section{A.W.}

${ }^{16}$ The author of the "Observations" was, of course, Benjamin Rush. Rush had sent Wayne a copy of the pamphlet, which had appeared initially as a series of four letters to the Pennsylvania Journal in May and June, I777, under the pseudonym, "Ludlow." Hawke, Rush, ig8-201. In forwarding the pamphlet, titled Observations Upon the Present Government of Pennsylwania. In Four Letters to the People of Pennsylvania, Rush commented, "In my opinion the government of Turkey is not more to be dreaded than the government of Pennsylvania." Butterfield, ed., Letters, I, I50-5 I. Wayne agreed with Rush that the constitution was defective, but at that point he was more concerned with the war effort than with politics. Stillé, Wayne, 70-7I.

${ }_{17}$ The reference is to the Reverend Joseph Montgomery (I733-I794), who had married Rush's sister Rachel. A graduate of Princeton, he was a Presbyterian clergyman in Delaware and a chaplain in the army. He later served in the Pennsylvania Assembly and the Continental Congress. Butterfield, ed., Letters, I, i 3 in.

${ }^{18}$ Brigadier General Charles Scott commanded a Virginia brigade and was actively engaged in the skirmishing that preceded the final withdrawal of the British from Perth Amboy. Fitzpatrick, ed., Writings, VIII, 307, 309, 310, 322, 324. 